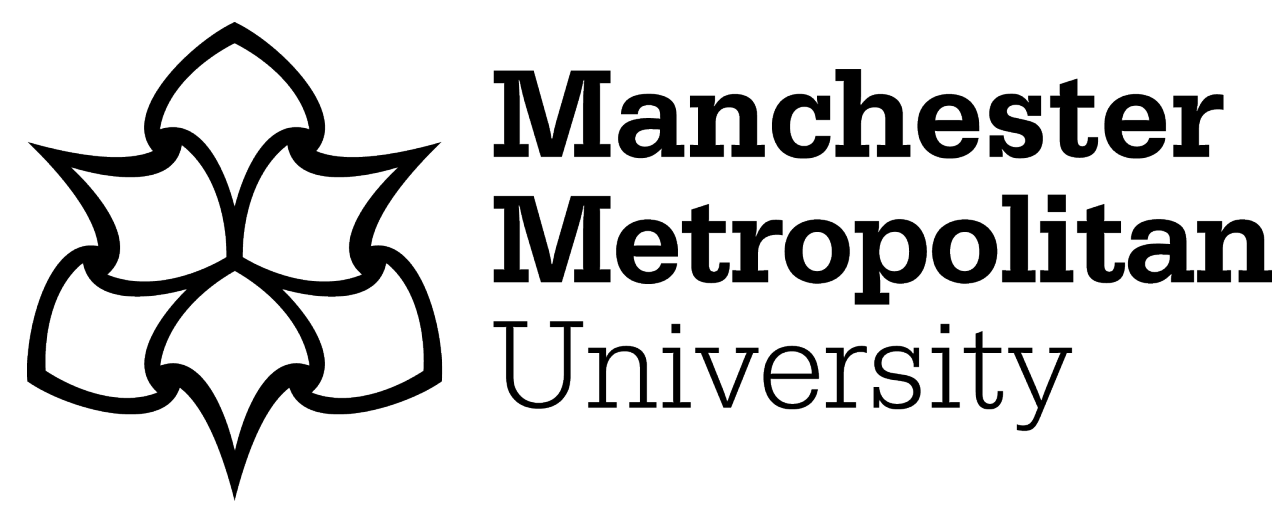

Thomas, Gareth, Elliott, Eva, Exley, Eve, Ivinson, Gabrielle ORCID logoORCID: https://orcid.org/0000-0002-5552-9601 and Renold, Emma (2018) Light, Connectivity, and Place: Young People Living in a Post Industrial Town. Cultural Geographies, 25 (4). pp. 537-551. ISSN 1474-4740

Downloaded from: https://e-space.mmu.ac.uk/619850/

Version: Accepted Version

Publisher: SAGE Publications

DOI: https://doi.org/10.1177/1474474018762811

Please cite the published version 


\title{
Light, Connectivity, and Place: Young People Living in a Post-Industrial Town
}

\author{
Gareth M. Thomas a, Eva Elliott a, Eve Exley a, Gabrielle Ivinson b, and Emma Renold a \\ a School of Social Sciences, Cardiff University, UK \\ ${ }^{\mathrm{b}}$ Faculty of Education, Manchester Metropolitan University, UK
}

\begin{abstract}
This article reports on a study of how young people in a post-industrial UK town reflect on their sense of health, place, and identity. Drawing on fifty-six qualitative interviews with 14-15 year olds, we explore how young people negotiate public space and how public lighting and darkness affect interactions with their surroundings. The young people provide an insight into how dark places ignite strong feelings of anxiety and danger, deeply fuelled by the environment itself together with rumours, lived knowledge of the locale, and symbolic boundaries shaping identities of belonging and exclusion in a context of structural inequality. Young people's understandings of place are configured and energised by multiple sources, such as personal experiences and social locations, material landscapes, and powerful discourses historical and contemporary - conveyed via stories, cautionary tales, and stigmatising media representations. We describe how the young people organised a public campaign to, among other things, install streetlights in a dark location. Their activism demonstrates how street-lighting, or its absence, is both emblematic of the importance of connectivity and place in their lives, and a manifestation of material (political) abandonment and (class) devaluation.
\end{abstract}

\section{Introduction}

All social life happens in some degree of light and dark. Both structure how we interact with others, position ourselves within these encounters, and navigate certain locations, particularly public places. Darkness is disruptive in this respect as it becomes harder to judge depth and distance, details are obscured, colours muted, and one is obliged to compensate for this loss of visual acuity by drawing on the other senses'. ${ }^{1}$ It also forces people to think through their body with regard to their surroundings, thus challenging understandings of their ontological security, bodily presence, and the boundaries these generate. Two journal special issues ('Introduction to geographies of darkness' in cultural geographies, 20152; 'Geographies of the urban night' in Urban Studies, 20153) and a handful of other accounts have explored 
the positives and potentialities of darkness, ${ }^{4}$ how its slow disappearance from illuminated urban space is lamented, ${ }^{5}$ how it causes fear in populations if combined with absent streetlights, ${ }^{6}$ and how it offers occasions for deviancy, 'for trying to be someone the daytime may not let you be'.7 A recent research programme on public lighting also shows how it plays a prominent role in reflecting and reproducing inequalities. ${ }^{8}$ In social housing, for instance, the focus is on how lights provide maximum visibility for control and surveillance (e.g. enhancing CCTV quality) - in contrast to lighting being perceived as transforming cities into spaces of consumption, leisure, and fantasy. ${ }^{9}$

However, many studies focus on adults living in urban environments. Little research explores how people, and young people specifically, experience lightness and darkness in their everyday lives, particularly when navigating public settings. Moreover, little work examines how darkness intersects with social and cultural constructions of place, how such understandings are fuelled by local rumours/stories, lived knowledge, and symbolic boundaries within this space, and how the material degradation of places in high poverty (e.g. a lack of/broken streetlights) are perceived by its residents. Nye ${ }^{10}$ suggests that electrical light is so entangled in our daily lives that when it is suddenly absent, resultant darkness is considered abnormal and discomforting. For Nye, there is an unspoken assumption that energy abundance is 'natural', with darkened zones containing the unfamiliar, the strange, the primitive; such areas can be dangerous and intolerable, but only if there is consistent maintenance and functional facilities (i.e. if the area is not neglected).

Like Nye, we argue that there is much to gain by peering into darkness, a path which too few scholars have trodden. We should ask, for instance, whether dark places ignite fear among people or, as some literature on urban blackouts claims, ${ }^{11}$ offer opportunities for collectivity, solidarity, humanity, and/or adventure. Moreover, we can ask how do people perceive darkness/absent lighting. Baldwin ${ }^{12}$ argues that in the gaslight era of the 1800s, affluent city-dwelling Americans worried that the absence of artificial light would set off crime and riots among working-class urbanites. Accordingly, lights served a 'police function'13. Areas deemed unsafe were lit first, and locations seldom frequented by middle- and upper-class inhabitants were lit later. Street lighting, therefore, was a form of social control and came to symbolise a progressive society. Our study enabled us to explore if this attitude to lighting existed for young people in a place which has experienced some social neglect due to its status as a post-industrial UK town, and to ask if street-lighting is still connected to issues of progress, power, status, and civility.

Our study investigated how young people (all sighted) navigate the open landscapes around where they lived as well as the alleys, streets, pathways, parks and woodlands in and around their hometown of Ironhill (pseudonyms have been provided for people and places). Drawing upon fifty-six qualitative interviews with young people, we address relations between the material culture of their locale, including night-time mobilities, and how they experience and navigate their landscape. The young people described how darkened places ignite strong feelings of fear, isolation, and disconnection, together with how they placed a specific focus on darkness at night-time rather than darkness in daytime. For young residents, Ironhill is a place of connectedness, togetherness, and conviviality. Their sense of belonging 
contrasts with some of the more pejorative outsider policy and public/media accounts of the town, which we explore later in the article. Young people in Ironhill gave the impression of being able to navigate the natural and social landscape with ease, whilst feeling connected to people in public space. Feeling safe and secure was predicated on knowing where and when to walk, how to behave, and how to avoid certain spots, and afforded by the many micro-socialities which gave them a strong sense of communal belonging, with darkness disrupting the embodied familiarity of everyday life. At night, darkness seemed to make the familiar strange, and young people conveyed this by reciting stories and rumours circulating among local residents. Such stories and rumours resembled universally censured negative media representations which stigmatised and stereotyped residents. Their fears were expressed as a worry about stumbling upon the real or imagined 'other' in the dark, and they expressed a sense of being disconnected from the usual visual and material clues that enabled them to feel safe during the day.

In what follows, we briefly describe a public campaign organised by the young people that resulted in the installation of streetlights in a dark zone in Ironhill. Their public activism shed light on how they experience social inequality through the everyday lack of resources and amenities, and why they addressed the materialisation of inequality in a specific way. Once a location connected to a hub of industrial activity and innovation, Ironhill has suffered gradual but drastic ruptures in recent years. It is a place in which employment prospects are poor, welfare dependency levels are high, and where personal (e.g. residents' health) and public (e.g. funding cuts) problems are endemic. Along with experiencing deep political abandonment, people in Ironhill are highly stigmatised both by pejorative media accounts and, at times, by its own residents as a 'bad place', a place which is the manifestation of apathy, substance abuse, welfare fraud and poor health/living (discourses feeding into neoliberal configurations of people living in similar towns). This vilification and sense of abandonment manifests at a material level, for instance, via an infrastructural disregard of place (such as broken and/or absent streetlights). It was clear that throughout the campaign, fixing the lights, even in one small area, was a mode of 'care' that was significant not simply for wayfinding but, also, for reconnecting the bonds of sociality, visually and symbolically, with other members of their community. Light and darkness, thus, can be viewed as material and symbolic. ${ }^{14}$ Landscapes are woven into residents' everyday lives (and vice versa) ${ }^{15}$ and young people's understandings of place - as the field of children's geographies often shows us ${ }^{16}$ - are formed and fuelled by multiple sources, such as personal experiences and social locations, material landscapes, and a plethora of local stories, rumours, cautions, and media accounts. ${ }^{17}$

\section{Method}

The study involved young people (aged 14-15) who were invited by the research team to map their experiences and perceptions of health and place in Ironhill. This article mostly reports upon interviews with fifty-six young people using geographic information system (GIS) technology, a digital spatialmapping tool designed to capture, visualise, and analyse geographical data to characterise spatial trends. Participants were recruited via two comprehensive secondary schools. The research team worked with 
teachers to identify pupils living in Ironhill. The young people were asked to attend a session where we introduced the study and invited them for interview. Of the 68 young people approached, 12 did not participate. Interviews were 35-55 minutes long. The participants (30 females, 26 males) were aged 14-15, mostly White, and typically brought up in Ironhill (although dispersed across distinct neighbourhoods within the boundaries of Ironhill). All lived at home with family and many of their parents were employed in low-pay work or were unemployed.

Interviews were carried out one-to-one with young people using a GIS 'app' on an iPad. Researchers began by asking young people to answer questions about demographics (age, gender, ethnicity, parents' employment) which were entered into the app. Following this, participants used the GIS app to map out their 'home neighbourhood', as they defined it, using a 'draw' tool. Referring to this shaded area, we asked what they liked/disliked about their neighbourhood and asked them to discuss their perceptions of health, place, and their relationships in Ironhill.

Participants were subsequently asked to 'draw' other Ironhill locations which they liked/disliked and where they felt un/safe on the app. Locations were categorised by young people as 'positive', 'negative', 'positive and negative', or 'neutral' (the four options offered by the app). When young people said what they disliked about certain areas, this would be identified through the use of 'signals' on the GIS app. In the app, signals were used to map certain characteristics - including the presence of drugs (users or paraphernalia), violence, vandalism, high noise levels, a lack of road safety, or other modes of 'social disorder' - to a specific place. For example, if a young person believed that one area was unsafe due to the presence of drug users, this would be 'mapped' to this location using the app. This would be discussed with the young person with respect to what happens, when it happens, the effect it has on them, the possible tensions, and whether there has been a response by relevant authorities (e.g. police, government). The interview concluded by asking young people to reflect on Ironhill and how they feel it is perceived by themselves, other Ironhill residents, and outsiders (i.e. those not from the area).

In many ways, the interview replicated a 'traditional' format, with the GIS tool being used to supplement the verbal data (indeed, one can legitimately ask whether we could have produced the same data using a physical map and marker pens). GIS technology was selected as it was intended to allow users to produce multiple delineations of a location's boundaries and explore the meanings and identities attached to such places. It was based on existing technology used to map community perceptions and experiences of crime and anti-social behaviour to inform approaches to neighbourhood policing. ${ }^{18}$ In this research, the intention was to adapt the tool to enable participants to speak back to pathologising representations of young people and identify positive, as well as problematic, spaces in Ironhill. However, the app has some important limitations. For one, the nature of the software, and the study's timescale, meant it was impossible to make the required changes for this study. This meant that certain questions and functions were ignored and we simply added interview questions to allow us to record positive, as well as negative, experiences and perceptions of place. The questions, however, could still be interpreted 
as leading. Asking young people to map un/safe places, for instance, guides conversations in a very particular, and arguably problematic, way.

In addition, the research took place in a highly stigmatised area where social 'realities' of poverty are represented in media stories through 'no hope' narratives of despair by using stigmatising tropes reflected and reinforced by local policy. As the tool was mostly organised around problems and deficits, we were concerned that this study would strengthen this place-based stigma. This is a stigma that not only gets under the skin and becomes part of the social determinants of health and inequality, but is also associated with producing representations and data which neglects or distorts the everyday resources sustaining social, emotional, and physical wellbeing in a community setting. In short, the GIS app constrained and regulated the 'type of talk' possible and generated data that led young people to speak of people and/or place in particular ways. Whilst insights into damaging impacts are vital for understanding local experiences of poverty and inequality, equally as important are insights into the positive experiences of young people. Without qualitative insights generated in the interview, stories of light and dark would have emerged in the absence of tales of conviviality and connection. The relationship between these different accounts of place are vital to better understand the relational importance of light and darkness.

\section{Findings}

During interviews, young people focused on spaces associated with social problems in their town, such as instances of assault, drug/alcohol use, domestic abuse, and environmental issues (e.g. vandalism, litter, graffiti). Such events were perceived as impacting on their sense of wellbeing or, at least, were cited as irritants or grievances. According to the data, frequent comments were around public drinking (47/56 young people reported this), public drug use (46/56), and 'groups of people' in certain areas (33/56). Notably, many young people also discussed environmental issues; they bemoaned litter and drug paraphernalia together with incidences of vandalism, graffiti, dirt, derelict buildings, smashed glass, and noise. However, complaints of environmental degradation emerged alongside narratives about spectacular, sweeping landscapes. There was a clear frustration that the social impact of inequality and poverty deprived them of their access to a positive aesthetic and affective public identity resource, and that media representations of their town focused more on social problems than on more positive framings, namely, the beautiful scenery and 'friendly people' (more on this later).

Yet one issue they consistently highlighted as problematic in Ironhill was navigating dark public places. Of the 56 young people interviewed, 31 identified 'dark areas' as a major concern (fourth most popular 'signal' in our dataset). In what follows, we show how darkness generated narratives of fear and worry deeply fuelled by the material setting and social life in this community. Against the micro-sociality that was felt to be important for feeling safe and connected, young people's accounts of the dark spoke to feelings of exclusion, isolation, and anxiety. These sentiments circulate as local rumours, myths, and parental tales/cautions also govern how young people imagine and negotiate public spaces. Darkness robs young people of sights that, in daylight, enable them to navigate social encounters without concern. 
Indeed, 'dark talk' was the imaginative realm in which the processes of 'othering' emerged. Rumours seemed to circulate as moral fables which guided their behaviour but, in so doing, reinforced subtle exclusionary divisions. We want to recognise that in making a distinction between dark and light (spaces), we potentially reinforce a dualism whilst overlooking the many gradations of dark and light - the grey areas. However, the young people did not make such distinctions. Whilst light and dark are not binaries they are multiple and contested - we make use of the straightforward distinctions outlined by the young people, that is, between 'light' and 'dark'.

\section{Light relief: the material life of Ironhill}

Many young people highlighted inadequate streetlights as an issue in Ironhill. Megan tells us about a large park she would visit in the day but not at night, suggesting that boys with 'dangerous dogs' occupy this poorly-lit space:

That park's not really safe anymore. I've been there only twice since [boys arrived with dangerous dogs]. There's no lights there, and there's, like, little woodland paths and stuff. I wouldn't go there in the night.

Similarly, Jacob talks about a dark path besides a local hospital:

You've got a couple of lights and then there's this one big, massive tree covering about four lights. It's all pitch black. There was this girl who was waiting for her boyfriend there and a girl jumped [assaulted] her. [...] It's dark, it's scary. [...] It's also really close to where you'll always find marijuana bags. It's too dark. [...] You get bits of light but, the shadows it gives. Have you seen Five Nights at Freddy's [a series of indie survival horror point-and-click video games]? It gives that effect on you. Scary. If I walk home that way [at night], I'm scared then.

Jacob also tells us that he rarely sees people in this area, contributing to his sense of feeling 'scared' in the dark since this path is 'pitch black'. He reports that others have been attacked there and that undesirable groups, such as drug users or what many young people in this study call 'druggies', may occupy this space (marijuana bags constitute, for Jacob, drug users as a shadowy presence). For Jacob, the dark signifies danger. Similarly, Fiona says that since the streetlights in her neighbourhood are 'crap', she feels too anxious to walk in this space alone, so her mother meets her when it is dark. She also references the recent installation of light-emitting diode (LED) lights which she believes do not shine as brightly as 'regular' streetlights. Although spanning the same area, the spaces of the night differ from the same spaces in daylight. ${ }^{19}$ For instance, Jacob says that Kinton - a small area in Ironhill - is a 'nice place' but he 'scarpers after dark'. Sian also talks about her fear of walking in Ironhill alone at night, especially in places without streetlights: 
In the dark, it's scarier. When a car passes, [people] stop to look and when you walk from [park], it's the [industrial estate] there so there's no houses. [...] When I'm walking in the night, I don't like going there. There's all bushes at the side too. I just run across that. [...] Especially if it's raining or something, you've got your hood up, you can't see as much so I just run it. [...] If someone was behind you and chasing you, there's nowhere you can run into.

Sian talks about her anxiety when people in cars slow down as she thinks they may stop the vehicle (we discuss the gendered nature of fear later). Sian recognises how there is no route for escape in a secluded area; darkness induces insecurity because it obstructs visibility and recognition, creating 'a limitless source of blind-spots, shadows and potential places of entrapment'. ${ }^{20}$ This angst is acute when situations restrict choice or offer no alternatives, such as dark, narrow alleyways offering one route. Sian later adds 'you don't know who it could be' and she would feel safer with the addition of streetlights here and elsewhere, a request repeated by many young people. We found that some young peoples' requests for more, or at least brighter, streetlights were influenced partly by a concern over a lack of police presence and authority. Many of them lamented the presence of police community support officers, or what they commonly called 'plastic police', rather than those with a more formal authority.

Alexander relates his own feelings of safety specifically to lighting, saying that he feels safe in his own neighbourhood because 'there's a lot of street lights'. He states that he avoids all dark areas in Ironhill without streetlights:

Where I don't go is basically dark areas where there's no street lights, dark lanes and everything too. That's where most people hang round really, like older kids - nineteen years old or anything like that - and they're drinking and hang around there. After they've had a drink, they don't realise what they're doing and they may come at you. [...] I feel aware. I make sure I'm looking around myself seeing if there's anybody but normally, if I'm on the bike, I'm out of there in a few seconds. But if you're walking down there, you do feel nervous. It's really dark and you have your wits about you, you need to check.

Looking only at these data, young people seem to claim a relationship between darkness/no street lights and a fear of crime, ${ }^{21}$ the presumption being that lights make people feel safer $^{22}$ by increasing the surveillance of possible offenders, deterring them, and signalling investment in the community.23 However, such solutions reinforce the claim that the value of lighting in marginalised communities is for control and surveillance rather than to positively contribute to connectivity and mobility that darkness disrupts at night. Others contest, or at least question, the notion that streetlights are a solution to crime ${ }^{24}$ and the idea of 'designing out fear' by illuminating dark places. ${ }^{25}$ In this study, young people's narratives focused on potential hostilities in unlit spaces that disrupted their sense of connectedness and belonging 
in Ironhill. Such worries were regularly opened up via local stories and rumours that identified places in which the undesirable other was likely to dwell; 'it is not so much the dark itself, but who lurks in the dark that causes fright' ${ }^{26}$. We build upon this point below.

\section{Urban legends? The role of rumour}

Very few young people had experienced (or, at least, reported experiencing) any hostility or incivility in Ironhill, with many participants characterising it as a largely sociable place where people assist one another in various ways. Whilst most young people claimed that dark public places ignited feelings of fear and anxiety (i.e. darkness at home did not cause worry), they rarely reported experiencing any physical or emotional trauma there. This may be because they choose to avoid such sites, but how did they know to avoid them, or at least approach them with caution?

One avenue might be hearing fairy tales as young children that contain longstanding mythologies about light/darkness. For Zipes, ${ }^{27}$ such stories have staked a privileged place in the cultural and 'civilising' processes throughout the world; tales instruct children about accepted conduct, values, roles, and relationships. ${ }^{28}$ However, our data does not support this explanation, and such an interpretation moves us away from connecting micro accounts of young people's negotiations of place with 'macro' processes of inequality. We argue that this fear of dark places was intensified by local rumours/stories, together with second-hand experiences, parental warnings, policy and media discourses (e.g. film/television together with harsh media accounts), peer group discussions, and a knowledge of the local area. Indeed, young people commonly drew on local rumours and myths when describing dark places, including a stock of stories about others who were attacked. For example, Louise referred to a lane where 'people [were] being jumped, stabbed, raped', with her friend being 'jumped' there; 'it's all trees [...] because it's just so dark and no-one can see you so that's probably why everything happens there'. What is important here is how stories are used as the basis for young people's interpretations when navigating public spaces. They recalled scenarios which may, or may not, have happened to someone else in forming their narrative, and this influenced where they go and when/who with. Alison describes a park near her house as follows:

You can walk through the forest [in the park] to get to school, or you can walk on main roads. [The forest] is quite dark. [...] You kind of worry, I never walk down there. Not a lot of people go there. [...] People say stuff like people get kidnapped there. I don't know if it's true or not. [...] It's closed in as well so if anything did happen, there's nowhere you can go really, it's just the one way. There's nowhere you can go if anything happens. I've never seen a woman walk through there. [It makes me feel] nervous and you feel like someone's watching you or following you, it's like, [you have] to look over your shoulder. It's probably an easier way to walk home for me but I can't because it's not safe. I'm too scared. [...] I just don't go near that way. I choose the long way. 
Alison avoided the forest (despite being an easier route home) owing to reported kidnappings there, although she doubts the authenticity of this tale. In Ironhill, rumours circulate which tie specific events to locations. Some places are known or imagined as zones of exclusion, as 'social purgatories', ${ }^{29}$ at night. Talking about Penketh (a small area in Ironhill), Heini says:

Sometimes we pass [Penketh] in order to get to school but we don't actually go to the streets. [...] If I'm on my own, I don't think I'd feel safe, especially in the night. [...] They always say about the druggies and we don't know if they're true but [...] some people would probably jump me, because some people got jumped apparently somewhere around there.

Avoiding Penketh at night was prompted by stories of assault and 'druggies', although Heini - like others - questioned the legitimacy of this story. Another oft-told rumour, connected to territorial stigma, ${ }^{30}$ was that Penketh residents 'stole shoelaces'. Lucia explained:

I don't particularly like Penketh. There are loads of stories about it. I never go there. They jump people, someone was stabbed there or something. I was like, nope, not going there. [...] There's a lot of rumours but you never know with rumours. I think there's a story that someone stabbed an old guy and then there was another story that someone jumps them and steals their shoelaces. [...] That's why they say "oh don't go up Penketh, they'll steal your shoelaces." [...] But why go through all that trouble just to steal shoelaces? It makes no sense at all.

Our understanding is that this claim is a joke to mock Penketh residents as criminals willing to steal any personal property, however ordinary, but it seems some young people interpreted this in literal terms. Lucia also suggests that residents of Penketh 'jump' and harm others, which is why she avoids it. Here and elsewhere, young people's negative accounts of certain areas may be perceived as a strategy to distance themselves from the alleged blemish of place, to manage associations of territorial stigma prevalent in settings marked by steep inequalities.

Because young people are close to such spaces, their understandings of it are highly calibrated. Their accounts suggested that they create affective 'mental maps'31 consisting of paths, landmarks, districts, and edges. These affective contours guide where to go and not to go; growing up with a local(e) knowledge, by erecting real and imagined boundaries between areas, is vital for their own understandings of place and wellbeing. This knowledge appears to relate to rumour and gossip about who occupies such locations. A common rumour, for example, was that a Polish man, or two Polish men, had abducted a child in a specific lane, leading some young people to avoid it at night. There are possibly racial undertones to this story; whilst young people did not report witnessing or experiencing racial hostilities, walking in/near the lane invoked stories that fed into, and revitalised, wider discourses of racism. 
Noticeably, rumours were also gendered. Some young people reported concerns over the imagined presence of a male other dwelling in dark spaces. Another rumour was about a man working at a circus, located temporarily in a park, who lifted up a young girl's skirt (other variations include him attempting to remove her underwear) but who was not arrested. For Brittany, this rumour meant that she 'tends to stay away' from the park as she does not 'find it safe there', especially at night, and - imagining her presence - she would be 'scared' and 'conscious of my surroundings, trying to look to see if anyone was around'. The connection between dark spaces and gender has been explored, ${ }^{32}$ particularly with respect to street-lighting and the built environment. ${ }^{33}$ For example, Brands et al. ${ }^{34}$ carried out a study with university students in Utrecht to explore how lighting, policing, and 'undesired others' affected their sense of fear. They suggested that interventions in the built environment and zero-tolerance policing tactics are unlikely to reduce fear of crime in the night-time economy as much as research, policy, and media discourses have claimed.

In this study, the imagined (male) other was invoked to explain why young women avoided certain places at night. Other studies have found that women evade darkened places at night, relating to long historical legacies of the gendered power relations still linking public space to masculine territories where women fear an attack. ${ }^{35}$ Pain $^{36}$ and Valentine ${ }^{37}$ connect this to a fear of sexual violence fuelled by the media, experiences of gender-based violence, and parental warnings which restrict and regulate daily practices and relations. It is clear that a fear of dark spaces cannot be deterministically tied to single environmental issues, such as streetlights, alone. In our study, we capture how young people inscribe the landscape with meaning; the night may conjure up imaginations of a male stranger residing in exposed or enclosed spaces via rumour, along with second-hand experiences, parental tales/warnings, media discourses, and knowledge of the setting and its local details. However, the perceived presence of the imagined/real other in dark areas, and its relationship with young peoples' sense of wellbeing, was cited by several young people regardless of their reported gender.

\section{Real and imagined others}

Whilst rumours regularly alluded to the existence of an 'unknown' or imagined other lurking in the shadows, the presence of a 'real' other was based on young peoples' embodied local knowledge of the area and first- and second-hand experiences. The main concern for young people, it seemed, was that they could be 'jumped' (i.e. assaulted). Anticipating an unwelcome and predatory figure was cited by Susie when talking about feeling 'scared' and 'uneasy' in a local park:

There's a lot of forestry and I wouldn't go into that forest bit on my own. [...] I'd go with my friends and have done before. But say I was going to walk through it on my own, I just feel like someone is going to jump out at me. [...] I don't like it because it's just lots and lots of trees and there's loads of different paths, and I feel like I'm going to get lost. 
Similarly, Isaac provides an account of a dark stairwell near his home:

I wouldn't want to walk down there in the night on my own. It's been known as a jump area because there's no cameras. [...] People wait around the corners and I don't like it. It used to be pitch black, you couldn't see nothing, and when I used to go down the skate park, I used to walk up there. [...] It ain't that bad now because it's lit but it's still scary because it's dark. There's no light at the top of the steps.

Most young people, like Isaac, talk about their fear of darkness in relation to secluded spaces in which 'the social' is absent. They regularly referred to empty streets, alleys, paths, parks, graveyards, and churches which they defined as 'creepy', 'scary', 'eerie', 'spooky', 'horrible', and so on. The notion of creepiness was commonly highlighted by young people. Dominique discussed one such area in Ironhill:

People go up [to the area] and sit in the garages with the doors up. It's really creepy. They just sit and play really loud music. It's really weird. [...] You wouldn't walk the streets on your own because it's a bit creepy down there as there are a lot of old houses, old churches, and it's just not nice. [...] In the day, it can be okay. It's just in the night. When you walk past in the morning, there can be drug needles on the floor and stuff. It's a bit dangerous.

In many of the young peoples' explanations, the sinister figure in the night - real or imagined - seemed to be, in almost all cases, someone who used drugs, was homeless, an older man, and/or was simply the 'wrong kind of [person]', ${ }^{38}$ The gendered understanding of dark spaces and male others was highlighted by Beth, who described walking near an abandoned factory:

A lot of people go there in the nights and I just won't walk through it on my own. It's a bit weird because a lot of people walk through it, a lot of men, and there have been rumours about people jumping out on people in the nights there [...] Women and children because there's a lot of kids go through there [...] I wouldn't go on my own. I don't go through it in the night, even with my friends. Only the daylight. I go the long way around. [...] It's just a bit creepy really, there's no lighting there, there's an old building. It's just a bit weird. And the rumours don't make it any better. [...] I don't look, I just keep walking. Get me out! [...] It's just somewhere they go to be really off the main streets. I don't want to go through there.

Beth outlined her methods for navigating and avoiding this poorly-lit location. The presence of unidentifiable men connect with rumours of physical assault. Young people also equated this with other Ironhill areas, such as a local skatepark. For instance, Ellen describes a local shop in Penketh and how 
men there 'drink flagons of cider and stuff like that'. She described the place itself in an equally apprehensive way:

The houses are all really close, they're all in each other's way. [...] And it's back alleys and things like that. You don't know who's around there. I tend to avoid it if I can but sometimes you just can't. [...] The alleys aren't lit. Some streets are but then others just don't work, the lights don't work. So I don't feel safe. [...] [My parents] don't want me there. They don't even want me to go near it.

For Ellen, Penketh was linked to the possible presence of lurking individuals. Such areas are imagined as being the symbolic holding ground for the 'bad,' including those seen as responsible for the 'bad reputation' Ironhill has as reported in media outlets. Later in her interview, Ellen claimed 'intimidating' men loiter in Penketh. Interestingly, whilst the alleged presence of undesirable male others was common to young women, some young men also discussed this worry. For example, Robert discussed a footpath near his house:

I used to go down there with one of the boys from school, but we stopped because it's always rattling in the bushes and men are always there. [...] There's probably people hiding in there. [...] It's scary. When you walk down there, it's just two of you on your own. That's one place I really don't like to go. [...] You never know what you could find there. It's full of people doing drugs and drinking alcohol. [...] You can see packets from the needles too. It just makes me sick. I'm too afraid [to go by myself].

The 'rattling in the bushes' and presence of (older) men 'hiding' in the bushes scare Robert who is 'too afraid' to navigate it alone. Although he initially indicates that he is unsure who inhabits this space, Robert says it is 'full of people doing drugs and drinking alcohol'. Here, the undesirable other emerges as a group of people engaging in what Robert perceived to be anti-social behaviour. He later talked about drug users in the area and how it is known to be 'bad and rough', a reputation he partly agreed with, but that he also attributed to 'one or two people [taking] it a bit too far' and who ruin it for the 'many nice people' here. Again, the reputation of certain areas - influenced by familiarity with the built fabric (e.g. dark lanes and alleyways) and rumours and local knowledge circulating among young people and other community members at large - meant that young people feared and avoided such places, at least during the night. This related to a fear of the real or imagined 'other', often a large group of older males engaging in particular activities (e.g. drug/alcohol use).

\section{Streetlights, an underpass, and a team of zebras: a creative form of public activism}


Our data identifies how light and dark were a key part of the young people's narratives of everyday life in Ironhill. However, as highlighted earlier, the GIS app used within interviews had limitations. It produced leading questions and narrowed opportunities for participants to share more positive configurations of place. In addition, it focused on 'social problems' (e.g. drugs, crime) which, as well as influencing findings, could further stigmatise a denigrated town (several young people made a similar observation). As such, we continued discussions with young people in different forums. We used alternative methods of listening to young people, spending time in Ironhill prior to, and alongside, interviews to familiarise ourselves with residents and neighbourhoods. We were helped by local gatekeepers and with Eva Elliott, Gabrielle Ivinson, and Emma Renold having conducted research in Ironhill and surrounding areas for many years. An important component of sustaining ongoing trust between the university and local community was to work towards some action to address issues that they felt the research highlighted and were important to them.

Following interviews, we organised seven group sessions in one of the schools where we initially carried out the interviews. Eleven young people, some who were interviewed and some who were not (young people were identified with school staff and were invited by the research team to take part), were asked to work with [University] and Citizens UK, an organisation building diverse alliances of communities to 'organise for power, social justice, and the common good'. As collaborators, Citizens UK worked with the young people and research team during groups to identify issues, informed by earlier interviews, which young people wanted to change in Ironhill. Over a period of around three months, we ran various sessions - both inside and outside the school, including a local walking tour - in which different issues were discussed. Although the concerns debated in the group sessions were similar to the content of many interviews (e.g. worries over drug and alcohol use, litter, and dark spaces without streetlights), several other issues were identified that centred on a specific area in Ironhill. Indeed, young people focused on a popular location near a local hospital and youth centre, expressing concerns of $\mathrm{dim} /$ broken lights on a well-used path connecting different parts of Penketh, an underpass coated in litter (including drug paraphernalia), and the lack of a safe road crossing.

In the fifth session, the young people decided that they would lead a public campaign around these three concerns: advocating for more streetlights on the poorly-lit path, closing an underpass, and installing a zebra crossing on a busy road. Whilst young people highlighted other public issues in Ironhill (e.g. drug abuse, unemployment), a campaign was organised around issues which could feasibly (and relatively quickly) result in change. In session six, the group decided to involve other young people at a local youth centre in their campaign. They decided that they would invite local politicians and senior police officers to take a tour of the area in which they would outline their three-point plan. During the tour (final session), young people from the school and youth centre - dressed as zebras to draw attention to the request for a zebra crossing - explained to their guests how they felt when navigating these spaces, particularly at night. Following positive media coverage in local and national newspapers, and further meetings with local politicians, planners, and police, the local council advised the young people that if 
they obtained matched-funding, they would be able to implement their three-point plan (which they received two months after the final group session [tour]). Three months later, the underpass was filled, the crossing was installed, and streetlight installation was underway.

We highlight this triumph for several reasons. First, it is an example of a collaborative project offering a forum for young people to productively engage with different stakeholders. Second, it shows how light and darkness were key for how young people move and think through their landscape. We do not wish to argue that interventions in the built environment, such as installing streetlights, will solve all worries. Rather, we want to underline how lighting is part of people's symbolic and affective relations to place. We contend that young people experienced environmental degradation, including dimmed/broken/absent streetlights, as a material manifestation of neglect from powerful institutions. Darkness also disrupted the micro-sociality of space that is so crucial to their sense of identity and community bonding. Throughout the study, young people were quick to identify the many positives of living in Ironhill, such as the beautiful landscape and a strong sense of local belonging and communal identity. Their sense of safety was related to having many familiar others around; family members, friends, neighbours, and others were the 'eyes upon the street'. ${ }^{39}$ However, young people mostly associated safety and wellbeing with the taken-for-granted, everyday micro dynamics of interaction. Lucia described feeling safe in her neighbourhood as follows:

I like being there, it's really calm. Everyone knows each other on our street. [...] They're really nice. [...] My neighbours, every time I get home from school, if they're outside, they always say good morning, good afternoon.

Young people associated safety and wellbeing with close relationships which had both spatial and affective dimensions. Relations were maintained in local semi-public gatherings, such as parties, and through informal greetings. Darkness, however, punctured the accepted moral order of the microsocialities of trust stemming from verbal/nonverbal greetings, and conjured imaginative spaces of obscurity where 'others' might dwell. Yet darkened locations can also offer havens for young people where they can escape the gaze of disciplinary figures (parents, police). Thus, darkness may foster a sense of liberation; places which were sites of terror and suspicion for some were also places for other young people to gather and perform alternative identities. ${ }^{40}$ That said, despite recent accounts celebrating the virtues of darkness, ${ }^{41}$ the young people in Ironhill mostly framed it as a source of anxiety. Interviews and other engagements, including the activism campaign, captured how streetlights are as much about connectivity, belonging, and place as they are about safety, surveillance, and social control.

\section{Discussion}

In this article, by focusing upon the experiences of young people in a post-industrial UK town, we explore the complexity and local specificity of light and dark in their everyday negotiations of public 
space. For young people in Ironhill, darkness can ignite strong feelings of fear and discontent. These affective responses are sketched out, at length, with reference to material degradation as well as myths and stories, lived knowledge of the locale, and symbolic boundaries which construct identities of local belonging and exclusion (e.g. via othering). Others may theorise that the young people's concerns of navigating dark public spaces simply indicated a fear of crime ${ }^{42}$ and a belief that their campaign, as outlined above, was an organised response to confront worries around the public safety of themselves and others (although many dispute the claim that streetlights reduce crime/fear of crime and increase public safety $\left.{ }^{43}\right)$. However, our interpretation is different. For us, the young people's public campaign was an instance of young people reclaiming their space and, with this, a sense of connectivity and belonging which was 'lost in the dark'. Plagued by popular accounts of Ironhill which stigmatise and deride members of the community, young people involved in this study were intent on speaking back to insulting representations. Specifically, they wanted to communicate that Ironhill is a place of connectedness and sociability, and where they can navigate the landscape with relative ease. Because darkness disrupted micro moments which gave them a sense of communal belonging, the campaign represented one effort to recover this feeling of sociability and connectivity, and, also, to strengthen counter narratives of Ironhill. In short, the public campaign provided a forum for 'revolting'44 against scornful, classed discourses of welfare, apathy, and place-based stigma which emerged in popular media, such as television programmes and online/newspaper articles, described elsewhere as 'poverty porn'. ${ }^{45}$

Moreover, we argue that the young people's concerns about dark space, and their subsequent campaign, was a product of feeling a deep political abandonment. In Ironhill (and in similar locations), social injuries are real (e.g. material degradation) and symbolic (e.g. the blemish of place ${ }^{46}$ ). For young people in Ironhill, 'place' is used for making and expressing positive identities, ${ }^{47}$ yet broken/absent streetlights were interpreted as one symptom of an infrastructural disregard of place, intensified by discourses of (place-based) vilification. This departs from previous work linking the need for lighting to civilise, order, and regulate 'unruly' classes - i.e. to 'produce a safer, more orderly society' 48 - and to preserve darkness as a 'luxury good' for more affluent neighbourhoods to generate a pleasurable nightscape. ${ }^{49}$ In contrast, the young people in this study viewed unlit spaces as indicative of political neglect. Diminished resources which, in turn, lead to environmental degradation are an accumulation of economic and political conditions producing real material effects, and reproducing social class, in Ironhill. Young people lamented poor environmental conditions (including litter, drug paraphernalia, vandalism, graffiti, dirt, derelict buildings, smashed glass, noise, broken/dim/absent streetlights) and experienced parts of their neighbourhoods as locations where the State has disinvested, and where powerful institutions do not care for them. Geographies were sensed through feelings of rejection and insecurity, reminding them of inequality, desertion, and devaluation in a context of shrinking support and services at a local level.

In short, our article highlights how young people in Ironhill know and move within their worlds with reference to light and dark, and how a focus upon light and dark - regularly overlooked and under- 
theorised in accounts of how young people, as well as others, use public space - reveals how young people's experiences of place speak to issues of stigma, affect, class, policy, and inequality. For young people in this study, it seems that the 'moral and economic class project of neoliberalism under austerity and financial capitalism is realised in a distinctly spatial way'. ${ }^{50}$ Their campaign intended to combat both material abandonment and stigmatising narratives through representing their town as a place of civility and togetherness. We argue, thus, that taking light and dark seriously as key players in social interactions opens up possibilities for imagining and thinking about place, especially in contexts of inequality, class devaluation, and place-based stigmatisation.

\section{Acknowledgements}

The authors would like to thank the young people and many gatekeepers and collaborators (especially youth workers, teachers, Citizens UK activists, and school administration staff) for taking part in the project. Without their patience, kindness, and enthusiasm, the study and campaign would not have been possible. We also thank the anonymous referees and, especially, Dydia DeLyser for her support and attentive comments throughout the review process. The project was completed in collaboration with the Productive Margins collective.

\section{Funding}

This research was supported by the Economic and Social Research Council (ESRC) and the Arts and Humanities Research Council (AHRC) [grant number ES/K002716/1).

\section{Notes}

1. N.J.Morris. Night Walking: Darkness and Sensory Perception in a Night-Time Landscape Installation', cultural geographies, 18(3), 2015, pp. 315-42, p. 315.

2. T.Edensor. 'Introduction to Geographies of Darkness', cultural geographies, 22(4), 2015, pp. 559-65.

3. I.van Liempt, I.van Aalst and T.Schwanen. 'Introduction: Geographies of the Urban Night', Urban Studies, 52(3), 2015, pp. 407-21, p. 408.

4. M.Cook and T.Edensor. 'Cycling Through Dark Space: Apprehending Landscape Otherwise, Mobilities, [Online], 2014, pp. 1-19.

5. T.Edensor. 'Reconnecting with Darkness: Gloomy Landscapes, Lightless Places', Social and Cultural Geography, 14(4), 2013, pp. 446-65.

6. C.Boomsma and L.Steg. 'Feeling Safe in the Dark: Examining the Effect of Entrapment, Lighting Levels, and Gender on Feelings of Safety and Lighting Policy Acceptability', Environment and Behaviour, 46(2), 2011, pp. 193-212.

7. I.van Liempt, I.van Aalst and T.Schwanen. 'Introduction: Geographies of the Urban Night', p. 408.

8. M.Sloane, D.Slater and J.Entwistle, J. Tackling Social Inequalities in Public Lighting: A Report by the Configuring Light/Staging the Social Research Programme (London: LSE, 2016). 
9. S.Isenstadt, M.Maile Petty and D.Neumann. Cities of Light: Two Centuries of Urban Illumination (London: Routledge, 2015).

10. D.E.Nye. When the Lights Went Out: A History of Blackouts in America (Cambridge: MIT Press, 2010)

11. C.Yuill. 'Emotions After Dark: A Sociological Impression of the 2003 New York Blackout', Sociological Research Online, 9(3), 2004, 3.

12. C.Baldwin. 'In the Heart of Darkness: Blackouts and the Social Geography of Lighting in the Gaslight Era', Journal of Urban History, 30(5), 2004, pp. 749-768.

13. M.J.Bouman. 'Luxury and Control: The Urbanity of Street Lighting in Nineteenth-Century Cities', Journal of Urban History, 14(1), 1987, pp. 7-37.

14. T.Edensor. 'The Gloomy City: Rethinking the Relationship Between Light and Dark', Urban Studies, 52(3), 2015, pp. 422-38.

15. T.Ingold. Culture on the Ground: 'The World Perceived Through the Feet', Journal of Material Culture, 9(3), 2004, pp. 315-40, p. 333.

16. S.L.Holloway and G.Valentine. Children's Geographies: Playing, Living, Learning (London: Routledge, 2000).

17. P.E.Hopkins. Young People, Place and Identity (London: Routledge, 2010).

18. M.Innes, L.Abbott, T.Lowe and C.Roberts. 'Seeing Like a Citizen: Field Experiments in "Community Intelligence- Led Policing”, Police Practice and Research, 10(2), 2009, pp. 99-114.

19. H.Koskela and R.Pain. 'Revisiting Fear and Place: Women's Fear of Attack and the Built Environment', Geoforum, 31(2), 2000, pp. 269-80.

20. K.Painter. 'The Influence of Street Lighting Improvements on Crime, Fear and Pedestrian Street Use, After Dark', Landscape and Urban Planning, 35(2-3), 1996, pp. 193-201, p. 193.

21. B.C.Welsh and D.P.Farrington. 'Effects of Improved Lighting on Crime', Campbell Systematic Reviews, 4(13), 2008, pp. 1-51.

22. A.Peña-García, A.Hurtado and M.C.Aguilar-Luzón. 'Impact of Public Lighting on Pedestrians' Perception of Safety and Well-Being', Safety Science, 78, 2015, pp. 142-148.

23. G.Nair, J.Ditton and S.Phillips. 'Environmental Improvements and the Fear of Crime: The Case of the 'Pond' Area in Glasgow', British Journal of Criminology, 33(4), 1993, pp. 555-61.

24. J.Green, C.Perkins, R.Steinbach and P.Edwards. 'Reduced Street Lighting at Night and Health: A Rapid Appraisal of Public Views in England and Wales', Health and Place, 34(Jul), 2015, pp. 171-80.

25. H.Koskela and R.Pain. 'Revisiting Fear and Place', p. 270.

26. M.J.Bouman. 'Luxury and Control', p. 30.

27. J.Zipes. Fairy Tales and the Art of Subversion (New York: Routledge, 2012 [1983])

28. J.Zipes. The Irresistible Fairy Tale: The Cultural and Social History of a Genre (Princeton: Princeton University Press, 2012)

29. L.Wacquant. 'Territorial Stigmatization in the Age of Advanced Marginality', Thesis Eleven, 91(1), 2007, pp. 66-77, p. 67. 
30. L.Wacquant, T.Slater and V.B.Pereira. 'Territorial Stigmatization in Action', Environment and Planning A, 46(6), 2014, pp. 1270-80.

31. K.Lynch. The Image of the City (Cambridge: The MIT Press, 1960).

32. G.Valentine. 'The Geography of Women's Fear', Area, 21(4), 1989, pp. 385-90.

33. L.Sandberg and M.Rönnblom. “'I Don’t Think We'll Ever Be Finished With This': Fear and Safety in Policy and Practice', Urban Studies, 52(14), 2015, pp. 2664-79.

34. J.Brands, T.Schwanen and I.van Aalst. 'Fear of Crime and Affective Ambiguities in the Night-Time Economy', Urban Studies, 52(3), 2015, pp. 439-55.

35. H.Koskela and R.Pain. 'Revisiting Fear and Place'.

36. R.Pain. 'Place, Social Relations and Fear of Crime: A Review', Progress in Human Geography, 24(3), 2000, pp. 365-87.

37. G.Valentine. 'The Geography of Women's Fear'.

38. T.Oc and S.Tiesdell. 'City Centre Management and Safer City Centres: Approaches in Coventry and Nottingham', Cities, 15(2), 1998, pp. 85- 03, p. 85.

39. J.Jacobs. The Death and Life of Great American Cities (New York: Random House, 1961).

40. I.van Liempt, I.van Aalst and T.Schwanen. 'Introduction'.

41. T.Edensor and E.Falconer. 'Danes Le Noir? Eating in the Dark: Sensation and Conviviality in a Lightless Place', cultural geographies, 22(4), 2015, pp. 601-18.

42. K.G.Willis, N.A.Powe and G.D.Garrod. 'Estimating the Value of Improved Street Lighting: A Factor Analytical Discrete Choice Approach', Urban Studies, 42(12), 2005, 2289-303.

43. R.Pain, R.MacFarlane, K.Turner and S.Gill. 'When, Where, If, and But': Qualifying GIS and the Effects of Street-Lighting on Crime and Fear', Environment and Planning A, 38(11), 2006, pp. 2055-74.

44. I.Tyler. Revolting Subjects: Social Abjection and Resistance in Neoliberal Britain (London: Zed Books, 2013).

45. T.Jensen. 'Welfare Commonsense, Poverty Porn and Doxosophy', Sociological Research Online, 19(3), 2014, 3.

46. L.Wacquant. 'Territorial Stigmatization in the Age of Advanced Marginality'

47. K.Paton. 'Housing in "Hard Times": Marginality, Inequality and Class', Housing, Theory and Society, 30(1), 2013, pp. 84-100.

48. C.Baldwin. 'In the Heart of Darkness', p. 753.

49. M.Sloane, D.Slater and J.Entwistle, J. Tackling Social Inequalities in Public Ligbting.

50. K.Paton, V.McCall and G.Mooney. 'Place Revisited: Class, Stigma and Urban Restructuring in the Case of Glasgow's Commonwealth Games', The Sociological Review, OnlineFirst, 2017, p.16.

\section{Author biographies}

Gareth M. Thomas is a Lecturer in the School of Social Sciences at Cardiff University, UK. He is a sociologist interested in medicine, stigma, disability, place, and technology. Gareth recently published his first book - Down's Syndrome and Reproductive Politics: Care, Choice, and Disability in the Prenatal Clinic - based 
on his $\mathrm{PhD}$ research: an ethnography of two prenatal clinics in the UK. Gareth is co-editor (with Dikaios Sakellariou) of the forthcoming book Disability, Normalcy, and the Everyday, which will be published with Routledge in mid-2018.

Eva Elliott is a Senior Lecturer in the School of Social Sciences at Cardiff University, UK. She is interested in (among other things) health and regeneration, the determinants of health, lay knowledge, community, and 'civic intelligence'.

Eve Exley is a $\mathrm{PhD}$ candidate in the School of Social Sciences at Cardiff University, UK. Her PhD research aims to explore the experiences and treatment of male-to-female transgender prisoners.

Gabrielle Ivinson is Professor of Education and Community at Manchester Metropolitan University (MMU), UK. Gabrielle is a social and developmental psychologist who studies gender, education and poverty. Her research explores how place, and specifically post-industrial places, influence children's and young people's educational achievement and aspirations.

Emma Renold is Professor of Childhood Studies in the School of Social Sciences at Cardiff University, UK, and author of Girls, Boys and Junior Sexualities (2005), Boys and Girls Speak Out (2013) and Children, Sexuality and Sexualisation (with Ringrose and Egan, 2015). Inspired by feminist/queer materialist posthumanist theory, her research investigates how gender and sexuality come to matter in young people's everyday lives across diverse sites, spaces and locales. Recent projects (e.g. 'Production Margins') explore the affordances of co-productive, creative and affective methodologies to engage social and political change with children on gendered and sexual violence (see www.agenda.wales). 